\title{
NILAI PERUSAHAAN MANUFAKTUR DI BURSA EFEK INDONESIA DITINJAU DARI PERSPEKTIF KEBIJAKAN DEVIDEN DAN KEBIJAKAN HUTANG
}

\author{
Nani Rohaeni ${ }^{1}$, Syamsul Hidayat ${ }^{2}$, Ifat Fatimah $^{3}$ \\ ${ }^{1}$ Universitas Bina Bangsa Banten \\ nanirohaeni.nr09@gmail.com \\ ${ }^{2}$ Universitas Bina Bangsa Banten \\ syamsul.hidayat@binabangsa.ac.id \\ ${ }^{3}$ Universitas Sultan Ageng Tirtayasa, Banten \\ mastersyah@ymail.com
}

\begin{abstract}
This study aims to determine how the influence of dividend policy and debt policy to corporate value. This research was conducted at a manufacturing company listed in Indonesia Stock Exchange (BEI) period 2012-2016. Sampling using Puropsive Sampling. A total of 13 manufacturing companies listed on the BEI to be sampled in this study. Regression analysis used in this study to see the effect of independent variables on the dependent variable either together or individually. The analysis results show that during the period 2012-2016 both dividend policy and debt policy have no significant effect on corporate value
\end{abstract}

Keywords: Debt policy; dividend policy; corporate value.

(C) 2018 JBTI. All rights reserved

Article history : received 27 Jul 2018; revised 20 Agt 2018; accepted 20 Sep 2018

\section{PENDAHULUAN}

Setiap pemilik perusahaan akan selalu menunjukkan kepada calon investor bahwa perusahaan mereka tepat sebagai alternatif investasi maka apabila pemilik perusahaan tidak mampu menampilkan sinyal yang baik tentang nilai perusahaan, nilai perusahaan akan berada di atas atau dibawah nilai yang sebenarnya. Sedangkan nilai perusahaan bagi perusahaan yang sudah go public, dapat ditentukan oleh mekanisme permintaan dan penawaran di bursa, yang tercermin dari listing price (Karnadi,1993). Tujuan perusahaan adalah memaksimumkan nilai saham (Karnadi,1993). Tujuan perusahaan dalam jangka panjang adalah mengoptimalkan nilai perusahaan (Wahyudi dan Pawestri, 2006).

Semakin tinggi nilai perusahaan, maka semakin sejahtera para shareholdernya. Nilai perusahaan ini sendiri dapat tercermin dari harga sahamnya (Fama, 1978; Wright \& Ferris, 1997; dan Walker, 200 dalam Hasnawati, 2005). Nilai perusahaan dapat digambarkan melalui harga pasar saham. Semakin tinggi harga saham yang dijual maka semakin besar kemakmuran yang diterima oleh pemilik saham bagi perusahaan yang go public. Nilai perusahaan dapat dilihat dari Price to Book Value (PBV) yang merupakan perbandingan antara harga saham dengan nilai buku per lembar saham (Ang, 1997). Berdasarkan perbandingan tersebut maka dapat diketahui apakah harga saham berada di atas atau di bawah nilai buku. PBV yang tinggi akan membuat investor percaya atas prospek perusahaan ke depan. 
Nilai perusahaan merupakan persepsi investor terhadap tingkat keberhasilan perusahaan yang sering dikaitkan dengan harga saham (Sujoko dan Soebiantoro, 2007). Harga saham yang tinggi membuat nilai perusahaan juga tinggi. Nilai perusahaan yang tinggi akan membuat pasar percaya tidak hanya pada kinerja perusahaan saat ini namun juga pada prospek perusahaan di masa depan. Memaksimalkan nilai perusahaan sangat penting artinya bagi suatu perusahaan, karena dengan memaksimalkan nilai perusahaan berarti juga memaksimalkan kemakmuran pemegang saham yang merupakan tujuan utama perusahaan (Euis dan Taswan, 2002).

Deviden memiliki peran yang penting dalam menjelaskan nilai perusahaan. Pembayaran deviden akan menjadi alat monitoring sekaligus bonding (obligasi) bagi manajemen (Copeland dan Weston, 1992 dalam Sofyaningsih, 2011). Besarnya dividen ini dapat mempengaruhi harga saham. Apabila dividen yang dibayar tinggi, maka harga saham cenderung tinggi sehingga nilai perusahaan juga tinggi. Sebaliknya jika dividen yang dibayarkan kecil maka harga saham perusahaan tersebut juga rendah.

Menurut Hendy (2008) deviden adalah pembagian sebagian laba perusahaan kepada para pemegang saham. Besarnya deviden ini dapat mempengaruhi harga saham. Apabila deviden yang dibayarkan tinggi, maka harga saham cenderung tinggi sehingga nilai perusahaan juga tinggi, sebaliknya, jika deviden yang dibayarkan kecil, maka harga saham perusahaan tersebut juga rendah. Kemampuan membayar deviden erat hubungannya dengan kemampuan perusahaan memperoleh laba. Jika perusahaan memperoleh laba yang besar, maka kemampuan membayar deviden juga besar.

Nilai Perusahaan merupakan persepsi atau penilaian investor terhadap suatu perusahaan, dimana sering dikaitkan dengan harga saham. Harga saham yang tinggi akan membuat nilai perusahaan juga tinggi. Nilai perusahaan atau juga disebut dengan nilai pasar perusahaan merupakan harga yang bersedia dibayar oleh calon pembeli apabila perusahaan tersebut dijual.

Kebijakan deviden berkaitan dengan kebijakan mengenai seberapa besar laba yang diperoleh perusahaan akan didistribusikan kepada pemegang saham. Besarnya deviden dapat mempengaruhi harga saham. Apabila deviden yang dibayarkan tinggi, maka harga saham cenderung tinggi sehingga nilai perusahaan juga tinggi. Sejalan dengan penelitian Azhari (2013) bahwa Kebijakan deviden berpengaruh positif dan signifikan terhadap nilai perusahaan.

Kebijakan hutang berkaitan dengan struktur modal karena hutang merupakan salah satu komposisi dalam struktur modal. Perusahaan dinilai berisiko apabila memiliki porsi hutang yang besar dalam struktur modalnya. Namun apabila hutang tersebut dapat menghasilkan keuntungan, maka hutang akan dapat meningkatkan nilai perusahaan. Sejalan dengan penelitian Azhari (2013) bahwa kebijakan hutang berpengaruh positif dan signifikan terhadap nilai perusahaan. Kemudian kebijakan hutang termasuk kebijakan pendanaan perusahaan yang bersumber dari eksternal. Sebagian perusahaan menganggap bahwa penggunaan hutang dirasa lebih aman daripada menerbitkan saham baru (Azhari, 2013).

Perusahaan-perusahaan manufaktur yang telah terdaftar di Bursa Efek Indonesia (BEI) dan telah go public, tentu sangat berhati-hati terhadap kepercayaan investor dalam menanam saham di perusahaan tersebut, karena kebijakan hutang dan kebijkan deviden sangat sensitif sekali bagi perusahaan. Maka penelitian ini bertujuan untuk menganalisis pengaruh kebijakan hutang dan kebijakan deviden terhadap nilai perusahaan pada perusahaan manufaktur yang terdaftar di Bursa Efek Indonesia (BEI) selama periode 2012-2016

\section{METODE PENELITIAN}

Penelitian ini hendak mengetahui dan membuktikan pengaruh kebijakan deviden yang diukur menggunakan Dividend Payout Ratio (DPR) dan kebijakan hutang diukur menggunakan 
Debt to Equity Ratio (DER) sebagai variabel bebas terhadap nilai perusahaan yang diukur menggunakan rasio PBV sebagai variabel terikat.

Populasi penelitian ini adalah seluruh perusahaan manufaktur di Indonesia yang terdaftar di BEJ periode tahun 2012 sampai tahun 2016. Sumber data penelitian diambil dari laporan keuangan tahunan 2017. Data penelitian diambil dengan metode purposive sampling terhadap perusahaan maufaktur yang terdaftar di BEJ. Sampel penelitian ini sebanyak 13 perusahaan manufaktur. Sesuai tabel 1:

Tabel 1. Sampel Penelitian Perusahaan Manufaktur

\begin{tabular}{lllll}
\hline \multirow{2}{*}{ No } & Code & \multicolumn{1}{c}{ Name } & Industry Sector & \multicolumn{1}{c}{ Industry Sub Sector } \\
\hline 1. & ASII & $\begin{array}{l}\text { Astra International } \\
\text { Tbk. }\end{array}$ & Miscellaneous & $\begin{array}{l}\text { Automotive And } \\
\text { Components }\end{array}$ \\
\hline 2. & AUTO & Astra Otoparts Tbk. & Miscellaneous & $\begin{array}{l}\text { Automotive And } \\
\text { Components }\end{array}$ \\
\hline 3. & UNVR & $\begin{array}{l}\text { Unilever Indonesia } \\
\text { Tbk. }\end{array}$ & $\begin{array}{l}\text { Consumer } \\
\text { Goods }\end{array}$ & Cosmetics and Household \\
\hline 4. & TCID & $\begin{array}{l}\text { Mandom Indonesia } \\
\text { Tbk. }\end{array}$ & $\begin{array}{l}\text { Consumer } \\
\text { Goods }\end{array}$ & Cosmetics and Household \\
\hline 5. & MERK & Merck Tbk. & $\begin{array}{l}\text { Consumer } \\
\text { Goods }\end{array}$ & Pharmaceuticals \\
\hline 6. & KLBF & Kalbe Farma Tbk. & $\begin{array}{l}\text { Consumer } \\
\text { Goods }\end{array}$ & Pharmaceuticals \\
\hline 7. & HMSP & HM Sampoerna Tbk. & $\begin{array}{l}\text { Consumer } \\
\text { Goods }\end{array}$ & Tobacco Manufacturers \\
\hline 8. & GGRM & Gudang Garam Tbk. & $\begin{array}{l}\text { Consumer } \\
\text { Goods }\end{array}$ & Tobacco Manufacturers \\
\hline 9. & INDF & $\begin{array}{l}\text { Indofood Sukses } \\
\text { Makmur Tbk. }\end{array}$ & $\begin{array}{l}\text { Consumer } \\
\text { Goods }\end{array}$ & Food and Beverages \\
\hline 10. & EKAD & $\begin{array}{l}\text { Ekadharma } \\
\text { International Tbk. }\end{array}$ & $\begin{array}{l}\text { Basic Industry } \\
\text { and Chemicals }\end{array}$ & Chemicals \\
\hline 11. & TOTO & $\begin{array}{l}\text { Surya Toto Indonesia } \\
\text { Tbk. }\end{array}$ & $\begin{array}{l}\text { Basic Industry } \\
\text { and Chemicals }\end{array}$ & Ceramics, Glass, Porcelain \\
\hline 12. & INTP & $\begin{array}{l}\text { Indocement Tunggal } \\
\text { Prakarsa Tbk. }\end{array}$ & $\begin{array}{l}\text { Basic Industry } \\
\text { and Chemicals }\end{array}$ & Cement \\
\hline 13 & Selamat Sempurna & Miscellaneous & Automotive And \\
& & Tbk. & Components \\
\hline
\end{tabular}

Sumber: Indonesian Capital Market Directory (ICMD)

Pengolahan data dilakukan dengan menggunakan program komputer SPSS versi 20 for Windows. Data yang menjadi sampel adalah data yang terdapat dalam laporan keuangan yang telah diaudit. Jenis data adalah data sekunder yang bersifat kuantitatif. Data diolah, disajikan, dan dianalisa untuk melihat hubungan/korelasi antara variabel independen dan variabel dependen. Selanjutnya model penelitian ini adalah:

\[ \mathrm{PBV}=\mathrm{a}+\beta_{1} D P R \]
\[ \mathrm{PBV}=\mathrm{a}+\beta_{2} D E R \]
Keterangan:
PBV : Price to Book Value Ratio (Nilai Perusahaan)
DPR : Dividend Payout Ratio sebagai proksi Kebijakan Deviden
DER : Debt to Equity Ratio sebagai prokso Kebijakan Hutang

Berdasarkan model penelitian, maka disusun hipotesis penelitian ini yaitu:

H1 : Kebijakan Deviden berpengaruh terhadap Nilai Perusahaan

H2 : Kebijakan Hutang berpengaruh terhadap Nilai Perusahaan 


\section{HASIL PENELITIAN DAN PEMBAHASAN}

Variabel yang diukur dalam penelitian ini yaitu DPR dan DER terhadap PBV. Sebelum lanjut kepada uji regresi maka dilakukan uji asumsi yaitu uji normalitas dan uji multikolinieritas.

Uji normalitas bertujuan untuk menguji apakah dalam model regresi, variabel pengganggu atau residual mempunyai distribusi normal. Pada penelitian ini digunakan uji statistik Kolmogorov-Smirnov untuk menguji normalitas data. Hasil uji normalitas dengan uji statistik Kolmogorov-Smirnov dapat dilihat pada tabel berikut:

Tabel 2: Hasil Uji Normalitas

\begin{tabular}{llr}
\hline & & \multicolumn{1}{c}{$\begin{array}{c}\text { Unstandardized } \\
\text { Residual }\end{array}$} \\
\hline $\mathrm{N}$ & \multicolumn{1}{c}{57} \\
\hline \multirow{2}{*}{ Normal Parameters ${ }^{\mathrm{a}, \mathrm{b}}$} & Mean & $0 \mathrm{E}-7$ \\
\cline { 2 - 3 } & Std. Deviation & $, 1,31275398$ \\
\cline { 2 - 3 } Most Extreme Differences & Absolute &, 100 \\
\cline { 2 - 3 } & Positive &, 103 \\
\hline Kolmogorov-Smirnov Z & Negative &, 780 \\
\hline Asymp. Sig. (2-tailed) & &, 576 \\
\hline a. Test distribution is Normal. & & \\
b. Calculated from data. & &
\end{tabular}

Pada tabel 2, menunjukkan bahwa nilai Kolmogorov-Smirnov adalah sebesar 0,780 dengan signifikansi sebesar 0,576 yang jauh diatas 0,05 yang berarti nilai residual terdistribusi secara normal atau memenuhi asumsi klasik normalitas.

Untuk mendeteksi ada tidaknya multikolineritas digunakan analisis perhitungan nilai Variance Inflation Factor (VIF). Apabila nilai VIF lebih besar dari sepuluh maka terjadi multikolinieritas. Berikut ini disajikan hasil pengujian VIF.

Tabel 3. Hasil Uji Multikolinieritas

\begin{tabular}{|c|c|c|c|}
\hline \multirow[t]{2}{*}{ Mode } & & \multicolumn{2}{|c|}{ Collinearity Statistics } \\
\hline & & Tolerance & VIF \\
\hline \multirow{3}{*}{1} & (Constant & & \\
\hline & ln_DPR & 973 & 1,028 \\
\hline & $\overline{l n \_D E R}$ & ,973 & 1,028 \\
\hline
\end{tabular}

a. Dependent Variable: $\ln \_$BV

Pada tabel 3 diatas menunjukkan bahwa nilai tolerance masing-masing variabel tidak ada yang dibawah 0,10 , begitu juga dengan nilai VIF tidak ada yang diatas 10 . Jadi, terbukti tidak terjadi multikolinearitas antar variabel bebas.

Untuk menguji hipotesis dalam penelitian ini, digunakan metode regresi linier sederhana. Secara statistik dapat diukur dari nilai statistik t, nilai statistik F, dan nilai koefisien determinasi (R2) yang dapat diamati pada tabel 4. 
Tabel 4. Hasil Uji Regresi

\begin{tabular}{|c|c|c|c|}
\hline Statistic & $\begin{array}{c}\text { Beta } \\
\text { (Standardized } \\
\text { Coefficients) }\end{array}$ & $\mathbf{T}$ & Sig. (P) \\
\hline (Constant) & & 14,802 & 0,000 \\
\hline Ln_DPR (X1) & $-0,193$ & $-1,450$ & 0,153 \\
\hline Ln_DER (X2) & $-0,161$ & $-1,215$ & 0,230 \\
\hline F hitung & 2,137 & & \\
\hline Sig.(P) & 0,128 & & \\
\hline $\mathbf{R}$ & 0,271 & & \\
\hline $\mathbf{R}^{2}$ (Squere) & 0,073 & & \\
\hline$\overline{\text { Adjusted } \mathbf{R}^{2}}$ & 0,039 & & \\
\hline
\end{tabular}

Dependent Variabel: $\ln \_\mathrm{BV}$

Sumber: data sekunder diolah di SPSS

Berdasarkan tabel 4 hasil uji t, dapat dilihat bahwa variabel DPR terhadap BV menunjukkan nilai t-hitung sebesar -1,450 dan nilai signifikansi sebesar 0,153 lebih besar 0,05 yang berarti Kebijakan Deviden tidak berpengaruh terhadap Nilai Perusahaan pada perusahaan manufaktur yang terdaftar di BEJ. Kemudian variabel DER terhadap BV menunjukkan nilai $\mathrm{t}$ hitung sebesar -1,215 dan nilai signifikansi sebesar 0,230 lebih besar 0,05 yang berarti Kebijakan Hutang tidak berpengaruh terhadap Nilai Perusahaan manufaktur yang terdaftar di BEJ.

Dari tabel 4 dapat diketahui nilai $F$ hitung sebesar 2,137 dengan taraf signifikansi sebesar 0,128. Hal ini berarti variabel DPR dan DER tidak berpengaruh terhadap variabel BV (Nilai Perusahaan) secara bersama-sama.

Nilai koefisien determinasi (adjusted R2) pada tabel 4 sebesar 0,073 atau 7,3\%. Hal ini berarti $7,3 \%$ variasi nilai perusahaan yang bisa dijelaskan oleh variasi dari kedua variabel bebas yaitu DPR dan DER, sedangkan sisanya sebesar 92,7\% dijelaskan oleh sebab-sebab lain diluar model.

Berdasarkan hasil analisis statistik dalam penelitian ini, ditemukan bahwa hipotesis pertama (H1) ditolak dan dapat disimpulkan bahwa kebijakan deviden tidak berpengaruh secara signifikan terhadap nilai perusahaan. Hasil penelitian ini tidak sejalan dengan teori Bird in The Hand yang diajukan oleh Gordon dan Lintner (1959) dalam Brigham (2001), yang menyatakan bahwa nilai perusahaan akan dimaksimumkan oleh rasio pembayaran deviden yang tinggi, karena investor menganggap bahwa resiko deviden tidak sebesar kenaikan biaya modal, sehingga investor lebih menyukai keuntungan dalam bentuk deviden daripada keuntungan yang diharapkan dari kenaikan nilai modal. Jika dilihat dari fenomena perusahaan maka bisa jadi nilai perusahaan manufaktur diukur dari tingkat loyalitas pelanggan terhadap perusahaan. Hasil pada penelitian ini tidak sejalan dengan penelitian terdahulu yang dilakukan oleh Azhari (2013), hasil penelitian ini sejalan dengan penelitian dari Mardiyati, dkk (2012). Kemudian hasil analisis statistik dalam penelitian ini ditemukan bahwa hipotesis kedua (H2) ditolak dan dapat disimpulkan bahwa kebijakan hutang tidak berpengaruh secara signifikan terhadap nilai perusahaan. Hal ini sesuai dengan Trade Off Theory, yang menyatakan bahwa sebelum mencapai suatu titik maksimum, hutang akan lebih murah daripada penjualan saham karena adanya tax shield. Jika dilihat dari fenomena yang ada bahwa perusahaan manufaktur memiliki cadangan pembantu hutang yang apabila ketika terjadi penurunan profit maka perusahaan mengambil kebijakan untuk menutupi kekurangan profit tersebut dengan cara mengambil dana cadangan pembantu hutang. Hasil pada penelitian ini tidak sejalan dengan penelitian terdahulu 
yang dilakukan oleh Azhari (2013), hasil penelitian ini sejalan dengan penelitian dari Mardiyati, dkk (2012).

\section{KESIMPULAN DAN SARAN}

Berdasarkan hasil penelitian dan pembahasan yang telah dilakukan, dapat diambil kesimpulan bahwa baik kebijakan deviden dan kebijakan hutang terbukti tidak berpengaruh scara signifikan terhadap nilai perusahaan manufaktur yang terdaftar di BEJ.

Beberapa saran yang dapat diberikan terkait dengan penelitian ini yaitu bagi perusahaan manufaktur hendaknya memperbaiki nilai perusahaan sehingga dapat menarik investor untuk berinvestasi pada perusahaan mereka, dan perusahaan emiten hendaknya juga mampu meningkatkan kinerja keuangannya agar dipandang baik di mata investor. Bagi investor, dalam memberikan penilaian terhadap suatu perusahaan sebaiknya juga memperhatikan faktor lain yang mempengaruhi nilai suatu perusahaan selain kebijakan hutang dan kebijakan deviden, seperti profitabilitas, ukuran perusahaan, pertumbuhan perusahaan, keunikan perusahaan, nilai aktiva, penghematan pajak, fluktuasi nilai tukar, loyalitas pelanggan dan keadaan pasar modal.

\section{DAFTAR PUSTAKA}

Ang, R., (1997), Buku pintar pasar modal Indonesia, Mediasor Indonesia.

Azhari, H., (2013), Pengaruh Kebijakan Hutang Dan Kebijakan Deviden Terhadap Nilai Perusahaan (Studi Empiris pada Perusahaan Manufaktur yang terdaftar di BEI), Artikel. Program Studi Auntansi Fakultas Ekonomi Universitas Negeri Padang.

Brigham, Eugene F. and Houston, (2001), Manajemen Keuangan, Edisi 8. Erlangga : Jakarta.

Euis, S., dan Taswan., (2002), Pengaruh Kebijakan Hutang Terhadap Nilai Perusahaan Serta Beberapa Faktor Yang Mempengaruhinya. Jurnal Bisnis dan Ekonomi. STIE STIKUBANK, Semarang.

Hasnawati, S., (2005a), Implikasi Keputusan Investasi, Pendanaan, dan Dividen Terhadap Nilai Perusahaan Publik di Bursa Efek Jakarta. No. 09/Th XXXIX. September 2005: 33-41.

Hendy, M.F., (2008), Istilah Pasar Modal A-Z. Jakarta: Elex Media Komputindo.

Karnadi, S.H., (1993), Manajemen Pembelajaran. Jakarta: Yayasan Promotion Humana.

Mardiyati, U., Ahmad, G.N. \& Putri, R., (2012), Pengaruh Kebijakan Dividen, Kebijakan Hutang dan Profitabilitas Terhadap Nilai Perusahaan Manufaktur Yang Terdaftar di Bursa Efek Indonesia (BEI) Periode 2005-2010. Jurnal Riset Manajemen Sains Indonesia (JRMSI). Vol. 3(1). Hal. 1-17.

Sofyaningsih, S., dan Hardiningsih, P., (2011), "Struktur Kepemilikan, Kebijakan Deviden, Kebijakan Utang, dan Nilai Perusahaan”. Dinamika Keuangan dan Perbankan. ISSN:19794878. Vol. 3 No. 1, Mei, 68-67.

Sujoko dan Soebiantoro, U., (2007), Pengaruh Struktur Kepemilikan, Leverage, Faktor Intern, dan Faktor Ekstern Terhadap Nilai Perusahaan (Studi Empiris pada Perusahaan Manufaktur dan Non Manufaktur di Bursa Efek Jakarta. Jurnal Manajemen dan Kewirausahaan. Vol. 9. No. 1. Maret, pp. 41-48.

Wahyudi, U., dan Pawestri, P.H., (2006), Implikasi Struktur Kepemilikan Terhadap Nilai Perusahaan: Dengan Keputusan Keuangan Sebagai Variabel Intervening. Simposium Nasional Akuntansi (SNA) IX Padang tanggal 23-26 Agustus 2006 dipublikasikan. 